\title{
Pediyatrik travma hastasına yaklaşım: Güncellenmiş gözden geçirme
}

\author{
Approach to the pediatric trauma patients: An updated review \\ Ahmet Baydın $^{\text {**, Ali Kemal Erenler }}{ }^{\mathrm{a}}$, Cengiz Çokluk ${ }^{\mathrm{b}}$, Türker Yardan ${ }^{\mathrm{a}}$, Burak Tander ${ }^{\mathrm{c}}$, Keramettin Aydın $^{\mathrm{b}}$, Yılmaz Tomak $^{\mathrm{a}}$ \\ Ondokuz Mayıs Üniversitesi Tip Fakültesi, Acil Tip Anabilim Dalı, Samsun \\ Ondokuz Mayıs Üniversitesi Tip Fakültesi, Beyin Cerrahisi Anabilim Dalı,Samsun \\ Ondokuz Mayıs Üniversitesi Tıp Fakültesi, Çocuk Cerrahisi Anabilim Dalı, Samsun
}

\begin{tabular}{|c|c|}
\hline \multicolumn{2}{|c|}{ MAKALE BİLGÍLERİ } \\
\hline \multicolumn{2}{|c|}{ Makale Geçmişi: } \\
\hline Geliş & $25 / 05 / 2010$ \\
\hline Kabul & $02 / 06 / 2010$ \\
\hline \multicolumn{2}{|c|}{ * Yazışma Adresi: } \\
\hline \multicolumn{2}{|c|}{ Ahmet Baydin } \\
\hline \multicolumn{2}{|c|}{ Ondokuz Mayıs Üniversitesi, } \\
\hline \multicolumn{2}{|c|}{$\begin{array}{l}\text { Tip Fakültesi, Acil Tıp Anabilim Dalı, } \\
\text { Kurupelit, Samsun }\end{array}$} \\
\hline $\begin{array}{l}\text { Kurupe } \\
\text { e-posta }\end{array}$ & @omu.edu.tr \\
\hline
\end{tabular}

\section{Anahtar Kelimeler:}

Pediyatrik travma

Travma yönetimi

Kafa travmasi

Göğüs travması

Batın travması

Sistematik yaklaşım

\section{Key Words :}

Pediatric trauma

Trauma management

Head trauma

Abdominal trauma

Systematic approach

\section{ÖZET}

Travma, 1 yaş üstü çocuklarda başta gelen ölüm nedenidir. Pediyatrik hastaların anatomik ve fizyolojik farklılıkları ve bu hastalara yaklaşım konusunda standart sağlanamamış olması klinisyenlerin karşılaştıkları zorluklardır. Organize olmayan yaklaşımlar bu hasta grubunda mortalitenin artmasına neden olmaktadır. Pediyatrik travma konusunda özelleşmiş merkezlerin kurulması en iyi yöntemdir. Bu mümkün olamıyorsa acil servis çalışanlarının eğitim ve tecrübe seviyesi arttırılmalı ve diğer bölümlerle iş birliği içinde belli standartların saptanması gerekmektedir. Travmalı hastalar için belli algoritmaların belirlenmesi ve uygulanması hastalar için hayati önem taşıdığı kadar, acil serviste çal1şanlar açısından iş yükünün azaltılmasında ve zaman kazanmada fayda sağlayacaktır. Biz bu çalışmamızda, güncel literatür 1şığında pediyatrik travmaya yaklaşımın sistematik hale getirilmesine katkı sağlamayı amaçladık.

J. Exp. Clin. Med., 2010; 27:127-136

\begin{abstract}
Trauma is the leading cause of death in children older than 1 year. Difficulties that clinicians are experiencing are the anatomical and physiological differences of pediatric patients and lack of a standardized approach to these patients. Disorganized approaches cause increase in mortality in this group of age. The best method is to set up centers specialized for pediatric trauma. If this is not possible, education and experience levels of emergency physicians must be increased and standards must be determined in relation with other departments. Besides vital importance of establishing and performing certain algorhytms for patients with trauma, it is also important for decreasing the workload and loss of time of emergency physicians. In this study, we aimed to contribute to systematic approach to the pediatric trauma in the light of current literature.

J. Exp. Clin. Med., 2010; 27:127-136
\end{abstract}

C 2010 OMÜ Tüm Hakları Saklıdır.

\section{Giriş}

Erişkin yaş grubunda olduğu gibi 1 yaş ve üzeri çocuklarda da ölümlerin en sık nedeni travmadır (İpekci, 2005). Pediyatrik travma hastasının yönetiminden sorumlu acil servis doktoru iki temel sorun ile karşı karşıya kalmaktadır. Birinci temel sorun pediyatrik yaş grubundakiler ile erişkinler arasındaki anatomik ve fizyolojik farklılıkların tanı, tedavi ve takipte yarattığı güçlükler, ikinci ise pediyatrik travmalı hastaya yaklaşım konusunda klinik tecrübe eksikliğinden doğan standart yaklaşımdaki sorundur. $\mathrm{Bu}$ sorunlar kalıcı sakatlıklara ve hatta hayatın sonlanmasına neden olabilmektedir. Travma geçiren çocukların ilk değerlendirmelerinin yapıldığ 1 acil servislerde, standart travma protokollerinin kabul edilmesi ve bu protokoller çer- çevesinde acil ekibinin travmalı çocuğu değerlendirmesi önem arz eder. Zira, travma organizasyonunun olmadığ 1 acil servislere başvuran çocuk travma olgularındaki ölüm oranlarının travma organizasyonunun bulunduğu acil servislere göre daha yüksek olduğu rapor edilmiştir (Osler ve ark., 2001). Biz bu yazımızda pediyatrik yaş grubundaki travma hastalarına güncel yaklaşımı yeni bilgiler ışı̆̆ında tartışarak acil hekimlerinin yararlanabileceği bir sistematik yaklaşım geliştirmeyi amaçladık.

\section{Travma hastasına genel yaklaşım}

Erişkin yaş grubunda olduğu gibi pediyatrik yaş grubunda da travma hastasına yaklaşım birincil değerlendirme ile başlar. Birincil değerlendirmenin amacı, travma 
geçiren bir çocuğun hızlı bir şekilde değerlendirilmesi ve etkin bir şekilde stabilizasyonunun sağlanmasıdır. Bu nedenle birincil değerlendirmeyi yapacak acil hekimi travmaya maruz kalan çocukta hayati tehlike oluşturan durumları tespit etmede ve bunların tedavisinde oldukça önemli görevler üstlenmektedir.

Birincil değerlendirme hava yolunun, solunumun, dolaşımın, bilinç durumunun ve çocuğun dış çevre ile ilişkisinin değerlendirilmesinden oluşur. Birincil bakıda havayolu açıklığını değerlendirecek doktor, çocuklardaki solunum yolu anatomisindeki farklılıklara ve kullanılan araçlara hakim olmalıdır. Solunumu değerlendiren acil hekimi takipne, burun kanatlarının solunuma katılması, homurdanma, interkostal çekilme, stridor ve wheezing gibi solunum yetmezliği belirtilerine dikkat etmelidir. Dolaşımın değerlendirilmesinde ise acil hekimi taşikardi, soğuk ekstremiteler, zayıf distal nabızlar, idrar çıkışında azalma, hipotermi ve kapiller dolum zamanında uzama gibi şokun erken belirtilerinin farkında olmalıdır. Travma geçiren bir çocuğun nörolojik muayenesi mümkün olduğunca hızı bir şekilde yapılmalıdır ve sistematik yaklaşım açısından da bu değerlendirme ya Pediatrik Glasgow Koma Skalası ile (Tablo 1) ya da AVPU skalası ile yapılmalıdır (Tablo 2). Dış çevreyle etkileşim olarak ifade edebileceğimiz basamakta ise hastanın açık yarası varsa bu yaraya uygun şekilde müdahale edilmelidir ve hasta hipotermi'den korunmalıdır (Hauda, 2000).

Çocuklarda hava yolu denetimi sağlanırken erişkinlerden farklı yanları göz önünde bulundurulmalıdır. Şöyle ki, supin pozisyonunda yatan bir çocukta oksiputun etkisiyle havayolunun kapanabileceği, dilin görece olarak büyük olduğu, orofarinks ve glottisin erişkine göre daha önde yerleşim gösterdiği bilinmelidir. Anatomik yönden bu farkl1lıklar çocuklardaki entübasyonu zorlaştırmaktadır. Çocuklarda, erişkinlerden farklı olarak entübasyon

Tablo 1. Pediyatrik Glasgow Koma Skalası.

\begin{tabular}{|c|c|c|}
\hline PUAN & GLASGOW KOMA SKALASI & PEDIYATRIKK MODIFIKASYYON \\
\hline & Gözler (>1 Yaş) & Gözler (>1 Yaş) \\
\hline 4 & Kendiliğinden açıllyor & Kendiliğinden açılıyor \\
\hline 3 & Sözlü komutla açılıyor & Konuşmayla veya seslenmeyle veya bağırmayla açilıyor \\
\hline 2 & Ağrılı uyaranla açılıyor & Ağrılı uyaranla açılıyor \\
\hline \multirow[t]{2}{*}{1} & Yanit alınamiyor & Yanit alınamıyor \\
\hline & En iyi motor yanıt (>1 Yaş) & En iyi motor yanıt (>1 Yaş) \\
\hline 6 & Sözlü komutlara uygun hareket ediyor & $\begin{array}{l}\text { Kendiliğinden hareketli ve çevreden gelen } \\
\text { uyaranlara uygun hareketleri var }\end{array}$ \\
\hline 5 & Ağrılı uyaranı lokalize ediyor & Ağrilı uyaranı lokalize ediyor \\
\hline 4 & $\begin{array}{l}\text { Ağrrlı uyarana normal fleksiyon yaparak çek- } \\
\text { me yanitı veriyor }\end{array}$ & $\begin{array}{l}\text { Ağrnlı uyarana yanıt olarak vücut bölümünü } \\
\text { çekiyor (Normal Fleksiyon Yanit1) }\end{array}$ \\
\hline 3 & \begin{tabular}{|l|}
$\begin{array}{l}\text { Ağrill uyarana anormal fleksiyon yanitı veri- } \\
\text { yor (Dekortike Yanıt) }\end{array}$ \\
\end{tabular} & $\begin{array}{l}\begin{array}{l}\text { Ağrilı uyarana anormal fleksiyon yanitı veriyor } \\
\text { (Dekortike Yanıt) }\end{array} \\
\end{array}$ \\
\hline 2 & $\begin{array}{l}\text { Ağrrl1 uyarana ekstansiyon yanitı veriyor } \\
\text { (Deserebre Yantt) }\end{array}$ & $\begin{array}{l}\begin{array}{l}\text { Ağrnl1 uyarana ekstansiyon yanitı veriyor } \\
\text { (Deserebre Yanit) }\end{array} \\
\text { (D) }\end{array}$ \\
\hline \multirow[t]{2}{*}{1} & Yanit alınamıyor & Yanit alınamıyor \\
\hline & En iyi sözlü yanıt (2-5 Yaş) & En iyi sözlü yanıt (2-5 Yaş) \\
\hline 5 & Anlamlı sözcük ve sözcükler kullanıyor & $\begin{array}{l}\text { Gülümsüyor, anlamsı ama nesesini ifade eden seslet } \\
\text { çıarıyor veya uygun ve anlamlı yerlerde ağlıyor }\end{array}$ \\
\hline 4 & Anlamsız ve uyumsuz sözler veya sözcükler söylüyor & $\begin{array}{l}\text { Irrite ağlama mevcut, genellikle ağlama durdurula- } \\
\text { biliyor, düzgün tepki vermiyor }\end{array}$ \\
\hline 3 & Ağlıyor veya çığlık atıyor ve her zaman susturulamıyor & Çığlıklar atarak ağlıyor, hiçbir şekilde susturulamıyor \\
\hline 2 & $\begin{array}{l}\text { Homurtu ve hirrlttlıt sesler çkariyor veya bilinç- } \\
\text { sizce ağlyyor ve hiçbir șekilde susturulamıyor }\end{array}$ & $\begin{array}{l}\text { Homurtu ve hirrlttll sesler çikariyor, asirt irritabl, yerin- } \\
\text { de duramıyor, ağrllı uyarana inilti ile yantt veriyor }\end{array}$ \\
\hline 1 & Yanit alınamıyor & Yanit alınamiyor \\
\hline
\end{tabular}

için en doğru seçim düz blade'in kullanılması ve epiglottisin direkt kaldırılmasıdır. Entübasyon sırasında kulland1ğımız tüpün solunum yoluna doğru ne kadar ilerletileceğini belirlemede entübasyon tüpünün numarası önemlidir. Kullanılan entübasyon tüpünün numarası 3 ile çarpılır ve bulunan sonuç dudak kenarına denk gelene kadar entübasyon tüpü solunum yoluna doğru ilerletilmelidir (örneğin; 4.0 numara entübasyon tüpü kullanıyorsak dudaktan 12 $\mathrm{cm}$ içerde olacak şekilde tüp solunum yoluna doğru ilerletilmelidir) (Phipps ve ark., 2005). Yine bir diğer fark da erişkinlerde vokal kordların bulunduğu bölge havayolunun en dar yeri iken çocuklarda en dar yer krikoid halkanın bulunduğu lokalizasyondur (Woosley ve ark., 2008). Havayolu yönetiminde ilk öncelik olası bir solunum yolu tıkanıklığını engellemek olmalıdır. Bu amaçla havayolu açıklığını sağlamak için "Jaw thrust ve chin lift" manevralar1 erişkinlerde olduğu gibi çocuklarda da uygulanabilecek manevralardır. Orofarinks debristen temizlenmeli ve oksijen desteği sağlanmalıdır. Sekiz yaşına kadar olan çocukların entübasyonunda cuff'sız tüplerin kullanımı önerilmekte ve kullanılacak tüpün çapı için çocuğun beşinci parmağının genişliği referans alınmaktadır (King ve ark., 1993). Sekiz yaşından büyük çocukların entübasyonunda ise cuff'lı tüpler kullanılmakta ve kullanılacak tüpün çap1 için yıl olarak yaşın dörde bölünmesi ile çıkan sonuca üç eklenmesi şeklindeki formül (yıl olarak yaş/4 + 3) kullanılmaktadır (Khine ve ark., 1997).

Solunum yönetiminde normal solunum sayısının yaşla beraber azaldığ 1 (infantlarda solunum sayısının dakikada 60 civarında iken büyük çocuklarda bunun 20 civarında olduğu) bilinmelidir. Perfüzyonu sağlayacak yeterli sıv1 tedavisi ile birlikte yeterli ventilasyon desteğinin pediatrik travma hastalarının resüsitasyonunda temel öğeler olduğu ise akıldan çıkarılmamalıdır (DeRoss ve ark., 2004). Asidoz varlığında yeterli ventilasyon sağlanmadan yapılacak bikarbonat infüzyonunun hiperkarbiye ve $\mathrm{pH}$ 'nin daha da düşmesine neden olacağ 1 da bilinmelidir (American College of Surgeons Committee on Trauma, 1997).

Dolaşım yönetimi esnasında, çocuklarda gelişebilecek olası şoku tanımak zordur. Zira çocuklarda hipotansiyon çok geç safhada ortaya çıkmaktadır ve hipotansiyon, kardiyovasküler kollaps'ın gelişmesinden hemen önce görülmektedir (Kincaid ve ark., 2001). Hipovolemik şokun tedavisinde dolaşan volümün yerine konması önemlidir. Bunun için 1lıtılmış kristaloid sıvıların $(\% 0.9 \mathrm{NaCl}$ veya Laktatlı Ringer) hızlıca $20 \mathrm{~mL} / \mathrm{kg}$ dozda bolus şeklinde verilmesi gerekir. Kristaloid sıvıların üç kez bolus şeklinde verilmesine rağmen, hipovolemik şokun bulguları kaybolmuyorsa hastaya mümkünse kendi kan grubundan

Tablo 2. AVPU skalası.

\begin{tabular}{|l|l|}
\hline A (Alert) & Uyanık, cevap veren, oryante. \\
\hline V (Verbal) & Sözlü uyaranlara cevap verir. Oryantasyon tam değildir. \\
\hline P (Pain) & Ağrllı uyaranlara tepki verir. Sözlü uyaranlara tepki vermez. \\
\hline U (Unresponsive) & Ağrılı ve sözlü uyaranlara tepki vermez. \\
\hline
\end{tabular}


$10 \mathrm{~mL} / \mathrm{kg}$ şeklinde kan verilmelidir. Kendi kan grubundan kanın bulunamadığ 1 durumlarda ise $0 \mathrm{Rh}(-)$ kandan vermek gerekir ve kan replasmanının hemen ardından da kanama odağının saptanıp tedavisi edilmesi gerekir (American College of Surgeons Committee on Trauma, 1997).

Birincil bakıda nörolojik muayene olarak nitelenebilecek "disability" basamağında hasta değerlendirilirken kullanılabilecek birkaç sistematik yaklaşım mevcuttur. Bir çalışmada, zehirlenmiş 1384 hastanın bilinç durumlarını değerlendirmede iki skala (AVPU ve Glasgow Koma Skalası) karşılaştırılmıştır. Bu karşılaştırmanın sonucunda Kelly ve arkadaşları her bir AVPU kademesinin Glasgow Koma Skalasında 15, 13, 8 ve 3'e karşılık geldiğini, kullanılabilirlik açısından avantajlı görülen AVPU skalasının acil ekibi için de daha kullanışlı olacağ sonucuna varmışlardır (Kelly ve ark., 2004). Literatürde bu konuda çocuklarla ilgili çalışma eksikliği olsa da her iki skalanın uygulanışı pediyatrik yaş grubundaki hastalar için olası belli sorunlar taşımakla birlikte mümkün olduğu durumlarda AVPU'nun hızlı ve etkili bir nörolojik muayene imkanı sağladığı söylenebilir.

Exposure basamağında hastanın elbiseleri dikiş yerlerinden kesilerek çıkartılmalı ve sonrasında vücudun ön ve sırt bölgeleri her türlü yaralanma açısından dikkatlice incelenmelidir. Travma sirasında herhangi bir toksik olaya maruz kalıp kalmadığı da yine bu aşamada belirlenmelidir. Ayrıca bu basamakta dikkat etmemiz gereken bir nokta da hastanın soyulduktan sonra vücut isısının korunmasıdır. Hastanın normal vücut sıcaklığını koruyabilmek için 1sı tutucu malzemelerden ve termal homeostazlı battaniyelerden faydalanılmalıdır (DeRoss ve ark., 2004).

Travmalı hastaları değerlendirmek için değişik anatomik ve fizyolojik skorlama sistemleri (Injury Severity Score, Abbrevated Injury Score, Revized Trauma Score, Pediatric Trauma Score, Pediatric Glascow Coma Score ...gibi) geliştirilmiştir. Bu skorlama sistemleri, travma hastalarına yaklaşımda bize etkin bir stratejinin belirlenmesinde fayda sağlamaktadır. Yani, bu skorlama sistemleri ile yaralanmanın ciddiyetini tahmin etmemiz ve bununla ilişkili olarak gelişebilecek komplikasyonları önceden belirleyebilmemiz olasıdır. Bu skorlamalardan biri olan Injury Severity Score (ISS), özellikle erişkin travma hastaları için hazırlanmış olup mortaliteyi, morbiditeyi ve hastanede kalma süresini belirlemede kullanılmaktadır. Travmalı hastaları değerlendirme kullanılan bir diğer skorlama sistemi ise anatomik skorlama sistemi olan Abbrevated Injury Score (AIS)'dur. Bu anatomik skorlama sistemine göre vücut altı anatomik bölgeye (baş-boyun, yüz, göğüs, abdomen, ekstremite, eksternal) ayrılmakta ve bu bölgedeki yaralanmalar 1'den 6'ya kadar puanlanmaktadır (1:minör, 2:orta, 3:ciddi, 4:şiddetli, 5:kritik, 6:kurtarılamaz). AIS'yi hesaplarken, bu anatomik bölgelerdeki yaralanmalardan en şiddetli olan üç tanesi alınır. Daha sonra bunların kareleri hesaplanıp, toplanır ve elde edilen sonuca bakılır. Üç ana- tomik bölgeden aldığı puan 16 ve üzerinde ise bu travma ciddi travma olarak değerlendirilir. Bu skorlama sistemine göre alabileceği en yüksek puan 75 olup her hangi bir lokalizasyonda AIS'ye 6 puan verilirse skor 75 olarak kabul edilir (Copes ve ark., 1988). Pediyatrik yaş grubundaki travmaları değerlendirmek için özel bir Pediyatrik Travma Sorlaması (PTS) geliştirilmiştir. Bu skorlama sisteminde altı tane parametre söz konusu olup her bir parametre için -1 ile +2 arasında puan verilmektedir (Tablo 3). Bu skorlama sistemine göre 8 ve altında puan alması ciddi mortalite ile birliktelik göstermektedir (Vella ve ark., 2006). Vella ve arkadaşları pediatrik travma hastalarında sıvı resüsitasyonunu ve belirteçlerini tartışmışlardır. Bu çalışmada Vella ve arkadaşları ileri yaşam destek kılavuzlarının genellikle erişkinler baz alınarak hazırlandığına atıfta bulunmuşlar ve hastalara resüsitasyon sırasında verilen sıvılar ile veriliş yolları, diğer hasta bilgileriyle beraber toplayarak çalışma yürütmüşlerdir. Erişkinlerde penetran yaralanmaların, çocuklarda ise künt yaralanmaların daha sık görüldüğü belirtilen bu çalışmada, erişkin travma hastalarında standart hale gelen iki adet büyük damar yolu açılması gerekliliğinin çocuklarda tartışmalı bir konu olduğu ve çocuklarda agresif sıvı tedavisine de genellikle ihtiyaç duyulmadığı sonucuna varılmıştır (Vella ve ark., 2006).

Tablo 3. Pediatrik Travma Skorlamas

\begin{tabular}{|l|c|c|c|}
\hline Klinik durum & \multicolumn{3}{|c|}{ Skor } \\
\hline & +2 & +1 & -1 \\
\hline Ağırlık & $20 \mathrm{~kg}$ & $10-20 \mathrm{~kg}$ & $10 \mathrm{~kg}$ 'ın altında \\
\hline Havayolu & Normal & Sürdürülebilir & Sürdürülemez \\
\hline Sistolik kan basıncı & $90 \mathrm{mmHg}$ & $50-90 \mathrm{mmHg}$ & $50 \mathrm{mmHg}$ 'nın altında \\
\hline Santral sinir sistemi & Uyanık & Bilinç bulanık & Koma/deserebre \\
\hline Açık yara & Yok & Minör & Major $/$ Penetran \\
\hline İskelet sistemi & Hasar yok & Kapalı kırı & Açık/Çoklu kırk \\
\hline
\end{tabular}

İkincil bak1 aşaması tüm vücut bölgelerinin ayrıntılı şekilde yaralanma açısından gözden geçirilmesi ve anamnezin derinleştirilmesini kapsar. Gerekli görülen grafiler ve laboratuar incelemeleri de bu aşamada istenir (Cornwell, 2000).

\section{Kafa travmaları}

Çocuklarda kafa vücuda oranla daha büyüktür ve bu büyük yapı ligamentöz dokuyla gövdeye bağlıdır. Sütür hatlarının kapanmamış olması, olası yaralanmalarda intrakraniyal basıncın daha iyi tolere edilmesine olanak sağlamaktadır. Çocuklarda kafa travmalarının en sık klinik görünümünün kusma, baş ağrısı ve letarji olduğu bildirilmektedir (Hauda, 2000). Kafa travması geçiren infant ve çocukların görüntülenmesi konusundaki yazısında Woodcock ve arkadaşlarının (2001) çıkarımları bize bu konuda yol gösterici olabilir. Kafa travması insidansinın yılda 95000 olduğu belirtilen bu yazıda kafa travmalar1nın etkileri primer ve sekonder olarak iki gruba ayrılmıştır. Primer yaralanmalar arasında kafatası kırığ 1 , kortikal kontüzyon ve epidural hematom sayllırken, sekonder yaralanmalar arasinda subdural hematom, kompresyon hasarı 
ve diffüz aksonal hasar (DAH) sayılmaktadır. Pediyatrik yaş grubunda kafa travmalı hastaların değerlendirilmesinde bilgisayarlı beyin tomografisi (BBT) altın standart olmakla birlikte BBT'si normal olan ancak nörolojik defisiti bulunan olgularda Manyetik Rezonans görüntüleme (MR) yapılmalidır.

Çocuklara özgü kafatası yaralanma şekli pingpong şeklinde oluşan çökme kırıklarıdır. Bu çökme kırığ1 çocuklarda kafatası kemiğinin membranöz yapısından kaynaklanan özel bir kırık şeklidir. Bebeklerde fizik muayenede adeta damar trasesi gibi ele gelebilen kırıklar birkaç ayda kendiliğinden düzelmektedir. Kafatasında kırık bulunan çocuk menenjit ve leptomeningeal kist komplikasyonları ile karşımıza çıkabilmektedir.

Epidural hematom, BBT'de dansite açısından subdural hematoma benzer özellik gösterir. Farklı olarak mercek şeklindedirler ve sütürlerle sinırlanırlar. Çocuklarda orta kraniyal fossadan ziyade tentoryum yakınında bikonveks, extra-aksiyel yerleşimli lezyon olarak görülürler. Pediyatrik yaş grubunda erişkinlerden farklı olarak epidural hematoma komşu kırık eşlik etmeyebilir. Araknoid ve dura mater arasında kan birikmesi olarak tanımlayabilecegimiz subdural hematom kortikal venlerin kopması sonucu oluşan kanamadır. Subdural hematom çocuklarda sıklıkla falks serebri ve tentoryum boyunca yayılır, hilal şeklindedir ve tüm hemisferi kaplayabilir. Üç güne kadar akut, dört ila yirmi gün arası subakut ve yirmi günün üzerindekiler kronik subdural hematom olarak kabul edilirler (Gentry, 1994). Subdural hematom'un dansitesi kanamadan sonraki 1-2 hafta içinde beyin parankimi ile aynı dansiteye ulaşır. Klinik sonuç ve sekel, subdural hematomun genişliğine, lokalizasyonuna ve cerrahi tedavinin zamanına bağlı olarak değişmektedir (Woodcock ve ark., 2001).

Diğer travmatik beyin hasarları arasında kontüzyon, hematom ve DAH sayılabilir. Travmanın olduğu bölgedeki kontüzyonlar coup, karşı tarafta oluşanlar contra coup lezyon adını almaktadır. Hematom ve kontüzyonların saptanmasında MRG, bilgisayarlı tomografi'den daha üstündür. Akselerasyon-deselerasyon esnasında aksonların kopması ve beyin parankiminin kafatasına sürtünmesi sonucu oluşan DAH bilinç bozukluğu ile kendini gösterir ve kötü nörolojik sonuçla ilişkilidir. DAH tanısı MRG'de beyin korteksi içinde küçük eliptik lezyonların görülmesi ile konmaktadır (Levin ve ark., 1993).

Kafaya penetran travma varlığında ölüm riski diğer vücut bölgelerine göre 3 kat fazladır. Bu durumda oksijenasyon, ventilasyon ve vücut 1sısı hızla düzeltilmelidir. Baş hafifçe yüksekte olacak şekilde yerleştirilmeli ve arteryel kan basıncı beyin perfüzyonunun indirekt göstergesi olarak kabul edilip sıvı resüsitasyonu ayarlanmalıdır. Birincil bakıdan sonra hastayı bilgisayarlı tomografiye gönderme konusunda tereddüt yaşamamak gerekir (Amick, 2001).

Direk kafa grafilerinin horizantal kırıklarda bilgisayarlı tomografiye üstün olduğu unutulmamalıdır. Bazı çalışmalar, intrakraniyal patoloji bulgusu olmamasına rağmen gereksiz BBT çekimi oranının \%40 ila 60 olduğunu ortaya koymuştur. İki yaşın altındaki çocuklarda mental muayenesi normal olanlarda, skalp hematomu saptanmayanlarda, 5 saniyeden az bilinç kaybı bulunanlarda, tehlikeli mekanizma ile travma geçirmeyenlerde ve palpe edilebilir kafatası kırığı olmayanlarda BBT çekilmesi gereksizdir. 2-18 yaş arasında BBT çekilmesini gerektirmeyen durumlar; normal mental durum, bilinç kaybı olmaması, baş ağrısı-bulantı olmaması, tehlikeli mekanizma ile oluşmamış travmalar ve kafa taban kırığı şüphesi olmamasıdır (Jimenez, 2010).

İntrakraniyal yaralanma açısından en fazla risk altında olan çocuklar somnole olanlar, mental durumlar1 bozuk olanlar, huzursuz olanlar, fokal nörolojik defisit saptananlar, deprese kafatası kırığ 1 saptananlar, fontanelinde şişlik olanlar, nöbet geçirenler, aşırı kusanlar ve 1 dakikadan fazla bilinç kaybı yaşayanlardır. Glasgow Koma Skalası (GKS) 8'den veya motor skoru 2'den düşük olan hastalar entübe edilmelidir. Travmatik beyin hasarından şüphelenildiğinde fenobarbital ( 2 ila $3 \mathrm{mg} / \mathrm{kg}$ ), diazepam $(0.25 \mathrm{mg} / \mathrm{kg}$ ) ve fenitoin (10 ila $20 \mathrm{mg} / \mathrm{kg}$ yükleme dozunu takiben 4 ila $7 \mathrm{mg} / \mathrm{kg} / \mathrm{gün}$ idame dozu) verilebilir. İntrakraniyal basıncı düşürmek için mannitol $(0.5-1 \mathrm{~g} / \mathrm{kg})$ ve furosemid (1 mg/kg) kullanılabilir (DeRoss ve ark., 2004).

Çocuklarda kafa travmaları her zaman kaza sonucu gerçekleşmeyebilir. Bu tür yaralanmaların belki de en ünlüsü Caffey (1946) tarafından tanımlanan "sallanmış bebek sendromu"dur. Dışarıdan belirgin travma olmaksızın retinal, subaraknoid ve subdural hematomların görülebildiği bu tablo hikaye ile klinik tablonun uyumlu olmaması durumunda akla getirilmelidir (Woodcock ve ark., 2001). Tanıya götüren en önemli etken hekimin şüpheci davranması ve çocuk suistimali kapsamında hastayı değerlendirmesidir. 1995-2003 yılları arasında $0-18$ yaş aralığındaki 2747 hastanın geliş şikayetleri, klinik özellikleri, acil servisteki durumları, taburculuk tanıları, hastaneye yatırılma ve taburcu özelliklerine göre tarandığı bir çalışmada çocuk travma hastalarında intrakraniyal patolojilerin saptanmasinda bilgisayarlı tomografi kullanımının giderek arttığ 1 ortaya konmuştur. Bunun nedeni olarak da çocuklarda bilgisayarlı tomografi çekimi için eşik algoritminin olmamas1 ve standart getirilememesi gösterilmiştir. Algoritma oluşturmaktaki en büyük sorun ise ne bilinç durumu ne de GKS'nin intrkraniyal patoloji göstergesi olarak yeterli olmaması gösterilmiştir (Blackwell ve ark., 2007).

İnsan büyüdükçe yüzün kafaya oranı da artmaktadır. Bunun bir sonucu olarak yaşla beraber kafa/yüz bölgesine olan travmalar yüz lehine artış göstermektedir. Fasyal yaralanmaya servikal hasarın eşlik etme oranı çocuklarda erişkinlere göre daha az olmakla birlikte fasyal yaralanma nedeniyle acil servise kabul edilen hastaların \%50'sine kafa yaralanması eşlik etmektedir. Çocuklarda fasyal yaralanma şüphesinde yağ dokusunun fazlalığına bağlı olarak hasarın gizlenebileceği ve gerektiğinde panoramik bilgisa- 
yarlı tomografi çekiminden kaçınılmaması gerektiği unutulmamalıdır (Costello ve ark., 2005).

\section{Servikal yaralanmalar}

Travmaya maruz kalan çocukların \%1,5'inde servikal hasar tespit edilir. Üst servikal bölgeden olan yaralananlarda mortalite oranı 6 kat fazladır. Servikal omur hasarlı çocukların \%17'sinde radyolojik olarak herhangi bir anormallik saptanamayabilir. Yapılan bir çalışmada 8 yaş altındaki ve üstündeki çocuklarda hasar sonucu nörolojik defisit gelişme oranı aynı bulunmuştur. Uygun radyolojik yöntemler kullanıldığında dahi tanıda fizik muayene çoğu zaman üstünlügünü korumaktadır (Patel ve ark., 2001). Penetran servikal spinal yaralanmalar değerlendirilirken boyun anatomik olarak 3 bölgeye ayrılır (Şek. 1). Zon 1: klavkula ile krikoid arası bölge, Zon 2: krikoid ile çene köşesi arası bölge, Zon 3: çene ile oksiput arasındaki bölgedir. Zon 1'deki proksimal, Zon 3'deki distal damarsal yapılardaki kanama kontrolü zor ve önemlidir. Zon 1'deki yaralanmalara anatomik lokalizasyoundan ötürü pnömotorkasın eşlik edebileceği unutulmamalıdır. Zon 3 yaralanmalar için acil serviste yapılacak çok şey olmadığ 1 ve acil operasyon endikasyonu bulunduğu hatırlanmalıdır (Amick, 2001).

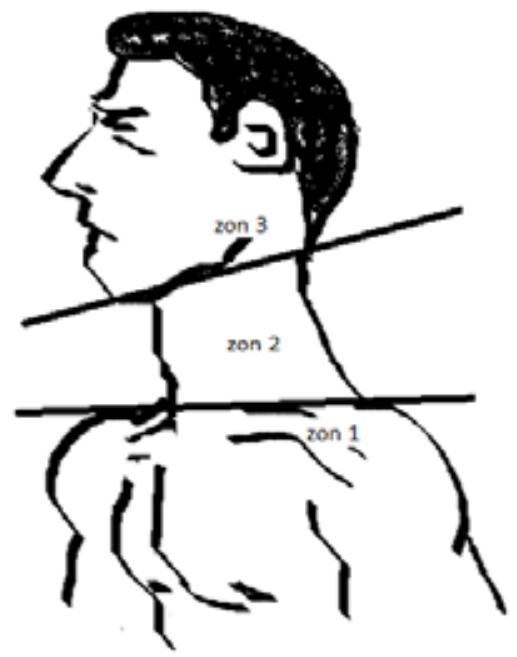

Şek. 1. Penetran yaralanmaların değerlendirilmesinde kullanılan servikal zon siniflamasi.

Servikal bölge yaralanmalarında bilgisayarlı tomografi çekimi altın standart olma özelliği çocuklar için de geçerlidir. Özellikle fokal nörolojik defisiti bulunan ve mental durumu bozuk olan tüm hastalara bilgisayarlı tomografi çekilmelidir. Servikal bölge yaralanmalarında yol gösterici olarak NEXUS kriterleri (Tablo 4) kullanılabilir (Jimenez, 2010).

Tablo 4. Servikal bölge yaralanmalarında radyolojik inceleme için NEXUS kriterleri.

Orta hat hassasiyeti yoksa, zehirlenme belirtisi yoksa, bilinç kaybı yoksa, fokal nörolojik defisiti yoksa ve ağrılı, dikkat dağıtıcı herhangi bir yaralanması yoksa radyolojik inceleme gereksizdir.

\section{Spinal yaralanmalar}

Çocuklarda spinal kolon daha esnek olduğundan hasar oluşumu erişkinlere göre daha zordur ve hasar oluşturacak mekanizma genellikle yüksek enerjili travmadır. Çocuklarda travma sonrası hiçbir radyolojik bulgu olmaksızın spinal hasarın gelişebileceği (SCIWORA) ve bu tür hasarların insidansının erişkinlerden daha fazla olduğu unutulmamalıdır. Tüm spinal kolon göz önünde bulundurulduğunda iki yaş altındaki çocuklarda en sık yaralanan bölge oksiput ile ikinci servikal vertebra arasıdır. Çocuklarda spinal yaralanmaların mortalitesi erişkinlere göre daha yüksektir (Hauda, 2000). Leonard ve arkadaşları (2007), spinal travma ve eşlik eden yaralanmalarla ilgili bir çalışmalarına ortalama yaşları 10 olan 40 hastayı dahil etmişlerdir. Ulaştıkları sonuçlar spinal travmalar içinde en s1k görülenin \%37,5 ile (15 hasta) servikal spinal yaralanmaların olduğunu ancak yine de gelişmekte olan omurganın biyokimyasal ve anatomik farklılıklarının insidansın daha yüksek olmasını engellediğini belirtmişlerdir. Literatürün aksine 9 yaş altı çocukların büyük çoğunluğunun servikal bölgenin alt kısımlarından yaralandığının ortaya koyulduğu çalışmada motorlu araç kazası sonucu oluşan spinal hasarların çoğuna ek yaralanmaların eşlik ettiği bulunmuştur. Buradan çıkan sonuç spinal travmalı her hastada hayatı tehdit edici başka yaralanmanın varlığının araştırılması gerektiğidir (Leonard ve ark., 2007).

\section{Toraks Travmaları}

Çocuklarda göğüs duvarı kompliyansının fazla olmasından dolayı dışarıdan kanıt olmaksızın ciddi intratorasik yaralanmaların olabileceğini unutmamamız gerekir. Çocuklarda ciddi toraks travmasının en önemli bulgusu ve/veya göstergesi gelişen kot kırıklarıdır. Ciddi toraks travması sonrası akciğer parankiminde oluşan en sık yaralanma ise akciğer kontüzyonudur ve bu durum erken dönemde direk grafilerde saptanamayabilir. İzole göğüs travmasında mortalite oranı \%4-12 arasında değişirken multitravmalı çocuklarda diğer sistem travmalarına ilave olarak toraks travmasinın bulunması durumunda mortalite oran1 10 kat artabilmektedir (Hauda, 2000). Ruddy 2005 yılında, toraks travmalı 6 olgu üzerinden yürüttüğü bir çalışmada gözlemlerini şu şekilde aktarmıştır; akciğer kontüzyonunun bulunduğu çocuklarda takipne, hipoksemi ve solunum zorluğu bulunur ve bu olguların oskültasyonunda akciğer seslerinde azalma, ral ve ronküs duyulabilir. Kaçak çok küçük olmadığı sürece travmatik pnömotoraks'da tedavi tüp torakostomi uygulanmasıdır. Tansiyon pnömotoraksın varlığında tüp torakostomi acil olarak uygulanmalı eğer tüp torakostomi acil olarak yapılamıyorsa iğne ile plevral aralıktan havanın çekilmesi gerekir. Arteryal kan gazında hipokseminin saptanması durumunda oksijen desteği verilmeli, sıvı kısıtlanmalı, ağrı yönetimi ve yeterli gida desteği sağlanmalıdır (Greaves ve ark., 2002).

Woosley ve arkadaşlarının gerçekleştirdikleri 
bir çalışmada akciğer kontüzyonuna bağlı olarak akciğer kompliyansı düşen çocukların erişkinlere göre daha fazla solunum yetmezliği riski taşıdıkları bildirilmiştir. Çocuklarda akciğer kontüzyonu \%30'a ulaştıktan sonra mekanik ventilasyon ihtiyacı katlanarak artmaktadır. Göğüs travması sonrasında gelişen hemotoraks, pnömotoraks varlığında tedavi amaciyla 8,5 Fr'lik pigtail drenaj kateteri veya gögüs tüpleri uygulanabilir. Perikardiyal tamponaddan şüphelenildiğinde hızlıca ekokardiyografi yapılmalı ve gerekirse perkardiyosentez ile sıvı boşaltılmalıdır (Testerman, 2006). Çocukların maruz kaldığı yüksek enerjili gögüs travmalarında kardiak kontüzyondan da şüphelenilmelidir. Bu durumda EKG çekilmeli ve kardiyak enzim düzeylerine bakılmalıdır. Çocukta ısrarlı hipotansiyon ve aritmi varlığında ekokardiyografi tanıya yardımcıdır (Ruppert ve ark., 2001). Toraks travması geçiren çocukların değerlendirilmesinde, şoka bağlı hipotansiyon gelişene kadar çocuklardaki kan basıncı ölçümünün dolaşım yeterliliğini göstermede fazla bir yararının olmadığı Woosley ve arkadaşları tarafindan raporlanmıştır. Aort yaralanması varsa kan basıncı ve kalp hızını düşürmek için beta bloker ilaçlar uygulanmalıdır. Göğüs travmasına bağlı diyafragma rüptürleri sık olmamakla birlikte $\% 1$ oranında görülebilmektedir (Collins ve ark., 2001; Sözübir ve ark., 2005). Diyafragma rüptürü genelde sol tarafta olur ve bu durumda gastrik tüple mide içeriğinin boşaltılması önemlidir (Woosley ve ark., 2008).

Toraksa penetran travma varlığında havayolu ve solunum stabilizasyonunun ardından dolaşım kontrolüne özel önem verilmelidir. Hastanın durumu stabil ve toraks içine geçişle ilgili kuşku varsa ampirik tüp yerleştirilmeden önce direk grafi çekilmelidir. Hemo/pnömotoraks saptandıktan sonra gögüs tüpünün yerleştirilmesi ile birlikte aşırı kan gelmesi durumunda otolog kan nakli düşünülebilir (Amick, 2001).

\section{Batın travmaları}

Çocuklarda batın travması varlığında fizik muayene iyi bir yol gösterici olmaktan uzak olabilir. Abdominal bölgede ezikler, abdominal distansiyon, hematüri, kusma, nörolojik bulgu, hematokritte düşme ve barsak seslerinin alınamaması gibi durumların varlığında bilgisayarlı tomografi ile batının değerlendirilmesi gerekir (Hauda, 2000).

Pediatrik yaş grubunda bulunan hastalarda künt batın travması ile ilgili olarak yapılan bir gözden geçirme yazısında Potoka ve arkadaşlarının çıkarımları yol gösterici olabilir. Buna göre künt batın travmasında en sık yaralanan organ dalaktır. Karın sol üst kadranda ya da sol alt torakal bölgede kontüzyon, sol kot kırıkları ve sol taraf hassasiyeti olası dalak yaralanmasının fizik muayene bulgularıdır. Genelde organ koruyucu izleme dayalı tedavi şekli tercih edilmekle beraber hemodinamik instabilite veya onarlamaz organ hasarının olduğu durumlarda ise splenektomiye gidilir (Wilson ve ark., 1992).

Künt travmalarda dalaktan sonra ikinci en s1k yaralanan organ karaciğerdir. Çoğu hafif yaralanma nonoperatif olarak takip edilmekle birlikte yine de hemodinamik yönden stabil olmayan hastalar için kan transfüzyonu ve laparatomi endikasyonunun bulunduğu unutulmamalıdır (Potoka ve ark., 2005; Bond ve ark., 1996; Patrick ve ark., 1999). Karın yaralanmalarında üçüncü sıklıkla yaralanan organ ise böbrektir. Böbrekler, çocuklarda karın içerisinde, erişkine göre daha fazla yer tutarlar ve bunların yaralanması nonoperatif tedaviye genellikle iyi yanıt verir. Künt batın travmalarında intestinal yaralanma nadir olsa da vertebralarla travma etkeni arasında kalan bağırsaklarda kompresyona bağlı olarak yaralanmalar görülebilir. Özellikle emniyet kemeri kullanımı sorgulanmalı ve emniyet kemeri izi olup olmadığ 1 inspekte edilmelidir (Newman ve ark., 1990). Bilgisayarlı batın tomografisinde intestinal yaralanmalar görülebilir (Moss ve ark., 1996; Ford ve ark., 1993).

Çocuklarda künt karın travmasına bağlı olarak izole pankreas yaralanmalarının görülmesi erişkinlere göre daha sıktır. Karın travmasına bağlı olarak pankreasin lumbar vertebra ile karın ön duvarı arasında baskıya uğraması sonucunda ezilmesi ile hasar oluşur. Çocuk popülasyonunda pankreatit ve pankreatik psödokistin en sik nedeni karın travmalarına bağlı pankreas yaralanmalarıdır. Amilaz ve lipaz seviyelerinin ölçümü ve bilgisayarlı tomografi görüntülemesi karın travması için mükemmel göstergeler olmamakla beraber en iyi tercihlerdir (Potoka ve ark., 2005).

Batına ve sirta penetran travma varlığında en sik yaralanan organlar kolon ve ince bağırsaklardır. Sirttan olan yaralanmalarda kemik ve kas dokusunun koruyucu yapısı organ yaralanması riskini azaltmaktadır. Sirkülasyonun stabilizasyonunun özellikle önem kazandığı bu gibi durumlarda s1v1 tedavisi konusunda agresif davranılmal1dır. Değişken klinik görünüm olasılığı söz konusu olduğundan sık aralıklarla fizik muayenenin yapılması gerekir. Peritoneal irritasyon bulguları, hemodinamik instabilite ve organ eviserasyonu varlığında ise hasta ameliyata alınmak üzere ameliyathaneye gönderilmelidir (Amick, 2001).

\section{maları}

\section{Pelvik bölge ve genitoüriner sistem yaralan-}

Çocuklarda pelvis kırıkları, özellikle de anterior halka kırıkları üretra ve mesane yaralanmalarıyla birliktelik gösterebilir. Pelvis kırığına bağlı kanamalar sonucu oluşan ölümler çocuklarda daha nadirdir. Hematüri varlığ çoğu zaman genitoüriner sistem (GÜS) yaralanmasını gösterir ve hematürinin derecesi ile yaralanmanın şiddeti arasinda paralellik vardır (Linzer, 2010). Asemptomatik mikroskobik hematürinin bilgisayarlı tomografi çekimi için endikasyon teşkil etmediği unutulmamalıdır. Üretral meada kan bulunması, rektal tuşede yüksek prostat saptanması 
ve anterior pelvik kırık varlığında aşağı GÜS yaralanması olasılığ bulunduğundan sistoüretrografi çekilmesi gerekir (Hauda, 2000).

Banerjee ve arkadaşları (2009) ortalama yaşları 1.4 y1l olan 44 pelvis fraktürlü olgu üzerinde gerçekleştirdikleri geriye dönük çalışmada pelvis kırıklarının yönetimini, hastanede yatış sürelerini ve klinik sonuçlarını literatürle karşılaştırmışlardır. En çok yaralanma mekanizmasının yayayken araç çarpması sonucu gerçekleştiğini ve kırıkların çoğunun immatüriteye bağlı stabil kırık olduğunu saptamışlardır. Yaralanmaların sıklıkla yazın ve kış ortasında gerçekleștiğini, pelvis kırığına en sık uzun kemik kırığının ve ikinci sıklıkta kafa travmasının eşlik ettiğini bildirmişlerdir. Hastaların \%25'inde tanıya yönelik olarak pelvis tomografisi çekilmiş ve tomografinin pelvis kırıklarının yönetimine ek bir katkı sağladığı saptanmamıştır. On üç yaş üzerindeki çocuklarda anstabil pelvis kırıklarına daha sık rastlamışlardır. Hastaların hiçbirinde şiddetli kanama kaydedilmemekle beraber mortalite oran $1 \% 16$ olarak saptanmıştır. Ölümlerin pelvis travmasına eşlik eden diğer yaralanmalar nedeniyle olduğunu bildirmişlerdir. Buradan çıkan sonuç, pelvis kırıklarının çocuklarda başlı başına ölüm nedeni olmamakla beraber şiddetli yaralanmanın bir göstergesi olduğudur (Banerjee ve ark., 2009).

\section{Anorektal bölge yaralanmaları}

Anatomik lokalizasyon itibariyle anorektal yaralanmaların tanısı zordur ve varlığında cinsel istismar mutlaka akılda tutulmalıdır. Parmakla yaranın, anal bölgenin ve vajenin eksplorasyonu sonrası gerekli görülürse proktoskopi, rektoskopi, vajinoskopi ve sistoskopi yapılabilir. En önemli komplikasyon olan enfeksiyonun önüne geçmek için vakit kaybetmeden üçlü antibiyotik tedavisinin (ampisilin, gentamisin, klindamisin) başlanması gerektiği bildirilmiștir (Amick, 2001).

\section{Ekstremite yaralanmaları}

Ekstremite yaralanmalarının yönetiminde en fazla dikkat gerektiren durum distal ve proksimal nabızların kontrolü ve var olan kanamanın kontrolüdür. Enfeksiyon riskini azaltmak için yara serum fizyolojik ile iyice yıkanmalıdır. Fizik muayenede vasküler yaralanmadan şüphelenilmesi durumunda USG yapilmalıdır. Muayenede ya da USG'de vasküler yaralanma saptanması durumunda arteriogram yapılmalıdır. Kirli yaralarda ve 6 saatten daha fazla bir süre geçmiş yaralarda geç kapatma uygulanmalıdır (Amick, 2001).

\section{Pediyatrik travma ve laboratuar ölçümleri}

Linzer'in (2010) yapmış olduğu bir çalışma pediatrik travmalı hastalarda laboratuar testlerinin ne kadar yararlı olduğunu tartışmaya açmıştır. Her ne kadar belirli standartlar ve eşik değerler getirilememiş bile olsa çocuklarda şok bulgusu olarak hipotansiyonun geç ortaya çık- ması gibi bir takım klinik problemlerin öngörülüp düzeltilmesinde yardımcı olabilecek testlerin çalışmaları halen devam etmektedir. Tam kan sayımında beyaz küre sayısı ile yaralanmanın şiddeti arasında bir korelasyon bulunmamakla birlikte hematokrit düzeyinde düşme, taşikardi ve hipotansiyon gibi hemodinamik instabilite kriterleriyle beraber beyaz küre sayısındaki artma, intra abdominal kanamanın bir göstergesi olabilir. Biyokimyasal parametrelerin hiç biri intraabdominal yaralanma için kesin bir belirteç olarak görünmemektedir. Isaacman ve arkadaşları (1993) yaptıkları bir çalışmada yüksek AST ve ALT seviyelerinin travmayla bir ilişkisinin olmadığını belirtmişlerse de, Chu ve arkadaşları (2009) 200 U/L üzeri AST değerinin ve $125 \mathrm{U} / \mathrm{L}$ ALT değerinin karaciğer yaralanması ile olası ilişkisini ortaya koymuşlardır. Pankreas yaralanmaları ile laboratuar sonuçları arasındaki korelasyonu inceleyen Namias ve arkadaşları (1996) ve Simon ve arkadaşları (1994) pankreas enzimlerinin ne yaralanma ne de bilgisayarl1 tomografi ile tetkik için gösterge olarak kullanılamayacağını belirtmişlerdir. Bununla birlikte, genitoüriner sistem yaralanmalı hastaların idrar mikroskobisinde 50 kırmızı kan hücresi/saha saptanması halinde bilgisayarlı tomografi ile ileri tetkik edilmesi gereklidir. Hematürinin şiddeti ile üriner sistem yaralanması arasinda korelasyonun mevcut olduğu Jeffrey ve arkadaşları tarafından bildirilmiştir (Linzer, 2010).

Kafa travmalarında koagülopati saptanması beyin parankim hasarı ve kötü prognoz ile birliktelik gösterir. Hymel ve arkadaşları (1997) özellikle protrombin zaman1nın beyin parenkim hasarı ile ilişkili olduğunu ortaya koymuşlardır. Tüm bu bilgiler 1şığında fizik muayene, karın içi yaralanmalarda ileri tetkik için en önemli belirteç olma özelliğini korumaktadır. Durumu stabil olmayan travma hastalarında hematokrit, kan grubu ve cross-match, PT, PTT ve INR ölçümleri gerekliyken transaminazların, idrar analizinin ve pankreatik enzimlerin çalışılmasının faydası ise tartışmalıdır. Yine de kanlar saklanabilir ve ileri tetkikler sonucunda karaciğer ya da pankreas yaralanması saptanırsa ilk değer görülmesi istendiğinde sonradan laboratuara gönderilip çalıştırılabilir. Akılda tutulması gereken diğer bir önemli tetkik de $\beta$-HCG'dir. Travmayla gelen üreme çağındaki tüm bayan hastalarda rutin olarak çalışılmalıdır (Linzer, 2010).

\section{Pediatrik Radyasyon Maruziyeti}

Hiroşima ve Çernobil'den edinilen kötü tecrübeler çocukların radyasyona daha duyarlı olduklarını, yaş azaldıkça kanser gelişim riskinin arttığını ortaya koymuştur. Bunun en büyük nedeni çocuklarda vücut yapısının daha ince olması ve hali hazırda replike olan hücre kümelerinin bulunmasıdır. Cevresel yıllık alınan normal radyasyon dozu $3 \mathrm{mSv}$ iken tek bir bilgisayarlı tomografi çekiminde 1 ila $14 \mathrm{mSv}$ doz alınmaktadır. İki yaş altında tek bir bilgisayarlı beyin tomografisi ile kanser gelişim riski $1 / 2000$ 'dir. Servi- 
kal bölge için hem erişkin hem de çocuk literatürü bilgisayarlı tomografi kullanımına olur vermektedir ancak unutulmamalıdır ki 3 yönlü direkt grafiye oranla tek bir servikal tomografi çekiminde 385 kat fazla radyasyon alınmaktadır. Çocuklarda bilgisayarlı batın tomografisi çekimi esnasında radyasyona en fazla maruz kalan organlar karaciğer ve midedir. Çocuklarda standartlaştırılamamakla beraber gereksiz tomografi çekiminin önüne geçilmesi, dolayısıyla kanser riskinin azaltılmasında tek umut karın travmalı hastalar için düşük maliyetli FAST (Focused Abdominal Sonography of Trauma) USG kullanımıdır (Jimenez, 2010). Scaife ve arkadaşlarının (2009) birinci seviye travma merkezlerine e-posta ile anket formu göndererek gerçekleştirdikleri bir çalışmada, FAST kullanımı konusunda hekimlerin tecrübeleri arttıkça erişkinlerde olduğu kadar hassas ve doğru şekilde çocuk hastalara da bu yöntemi uygulayabildiklerini ortaya koymuş ve FAST USG acil servis için "geleceğin stetoskobu'dur" denilmiştir.

\section{Sonuç}

Stylianos ve arkadaşlarının (2008) yaptıkları çalışmadaki gözlemleri dikkat çekicidir. Buna göre pek çok pediatrik travmalı hasta erişkin hastanelerinde tedavi edilirken travma merkezinin bulunmadığı yerlerdeki çocuk hastane- lerinde yapılan tedavilerden daha yüz güldürücü sonuçlar alınmaktadır. Yine bu çalışmadan çıkan sonuç travma merkezlerinde tedavi altına alınan çocukların travma merkezi olmayan hastanelere ya da çocuk hastanelerine oranla daha iyi bakım aldığını, pediyatrik travma merkezlerinin ise sağ kalım açısından hepsinden daha iyi olduğu yönündedir. $\mathrm{Ne}$ var ki tüm travma hastalarının bu merkezlerde bakılması pratik olmadığından pediatrik travma merkezleri ile erişkin travma merkezleri arasındaki farkın ilgili hekimlerin çocukluk dönemine özgü farkl1lıklar hakkında eğitilmesiyle kapatılabileceği belirtilmektedir (Stylianos ve ark., 2008). Travma merkezlerinin hasta bakımında bu denli ileri olmalarının nedeni personelin konu üzerine özel eğitim almış olmasının yanı sıra tecrübeler sonucu belli standartların konulmuş olması olabilir. 2006 yılında benzer çıkarımlara ulaşan Junkins ve arkadaşları (2006) pediatrik travma merkezi sisteminin halen çok yeni olduğuna ve travma bakımında optimum modellerin ve sistemlerin gerekli olduğuna vurgu yapmışlardır. Travmalı hastalar için belli algoritmaların belirlenmesi ve uygulanması hastalar için hayati önem taşıdığı kadar, acil serviste çalışanlar açısından iş yükünün azaltılmasında ve zaman kazanmada fayda sağlayacaktır.

\section{KAYNAKLAR}

American College of Surgeons Committee on Trauma (ACS COT): Transfer to definitive Care in ACS COT: Advanced Trauma Life Support for Doctors (ed 6), Chicago, IL, American College of Surgeons, 1997, pp 327-335.

Amick, L.F., 2001. Penetrating trauma in pediatric patient. Clinical Pediatric Emergency Medicine. 2, 63-70.

Banerjee, S., Barry, M.J., Paterson, J.M.H., 2009. Pediatric pelvic fraktures: 10 years experience in trauma centre. Injury. 40, 410-413.

Barsness, K.A., Bensard, D.D., Ciesla, D., Patrick, D., Hendrickson, R., Karrer, F.M., 2004. Blunt diaphragmatic rupture in children. J. Trauma-Inj. Infect Crit. Care. 56, 80-82.

Blackwell, C.D., Gorelick, M., Holmes, J.F., Bandyopadhyay, S., Kuppermann, N., 2007. Pediatric head trauma: changes in use of computed tomography in emergency departments in the United States over time. Ann Emerg. Med. 49, 320-324.

Bond, S.J., Eichelberger, M.R., Gotschall, C.S., Sivit, C.J., Randolph, J.G., 1996. Nonoperative management of blunt hepatic and splenic injury in children. Ann. Surg. 223, 286-289.

Caffey, J., 1946. Multiple fractures in the long bones of infants suffering from subdural hematoma. Am J. Roentgenol. $56,163-173$.

Chu, F.Y., Lin, H.J., Guo, H.R., Liu, T.H., Foo, N.P., Chen, K.T., 2009. A reliable screening test to predict liver injury in pediatric blunt torso trauma. Eur. J. Trauma Emerg. Surg. 36, 44-48.

Collins, J.N., Cole, F.J., Weireter, L.J., Riblet, J.L., Britt, L.D., Flynn, T.C., 2001. The usefulness of serum troponin levels in evaluating cardiac injury. Am. Surg. 67, 821-825.

Copes, W.S., Champion, H.R., Sacco, W.J., Lawnick, M.M., Keast, S.L., Bain, L.W., 1988. The Injury Severity Score Revisited. J. Trauma. 28, 69-77.

Cornwell, E.E. 2000. Initial Approach To Trauma. In: Tintinalli JE, Kelen GD, Stapczynski JS (eds).Emergency Medicine: A Comprehensive Study Guide 5th ed. New York: McGraw Hill; p.1609-1614.

Costello, B.J., Papadopoulos, H., Ruiz, R., 2005. Pediatric Craniomaxillofacial Trauma. Clin. Pediatr. Emerg. Med. 6, $32-40$.

DeRoss, A.L., Vane, D.W., 2004. Early evaluation and resuscitation of the pediatric trauma patients. Semin Pediatr. Surg. 13, 74-79.

Ford, E.G., Senac, M.O., 1993. Clinical presentation and radiographic identification of small bowel rupture following blunt trauma in children. Pediatr. Emerg. Care. 9, 139-142. 
Gentry, L.R., 1994. Imaging of closed head injury. Radiology. 191, 1-17.

Greaves, I., Porter, K.M., Revell, M.P., 2002. Fluid resuscitation in the pre-hospital trauma care: a consensus view. J. R. Coll. Surg. Edin. 47, 451-457.

Hauda, W.E., 2000. Pediatric Trauma. In: Tintinalli JE, Kelen GD, Stapczynski JS (eds).Emergency Medicine: A Comprehensive Study Guide 5th ed. New York: McGraw Hill; p.1615-1623.

Hymel, K.P., Abshire, T.C., Luckey, D.W., Jenny, C., 1997. Coagulopathy in pediatric abusive head trauma. Pediatrics. 99, 371-375.

İpekci, F., 2005. İlk ve Acil Yardım. In: Ertekin C, Taviloğlu K, Güloğlu R, Kurtoğlu M (editörler). Travma 1. bask1. İstanbul: İstanbul Tip Kitabevi 123-133.

Isaacman, D.J., Scarfone, R.J., Kost, S.I., Gochman, R.F., Davis, H.W., Bernardo, L.M., Nakayama, D.K., 1993. Utility of routine laboratory testing for detecting intra-abdominal injury in the pediatric trauma patient. Pediatrics. 92, 691-694.

Jimenez, R.R., 2010. Radiographic Evaluation of The Pediatric Trauma Patient and Ionizing Radiation Exposure. Clin. Pediatr. Emerg. Med. 11, 22-27.

Junkins, E.P., O’Connell, K.J., Mann, N.C., 2006. Pediatric Trauma Systems in The United States: Do They Make a Difference? Clin. Pediatr. Emerg. Med. 7, 76-81.

Kelly, C.A., Upex, A., Bateman, D.N., 2004. Comparison of consciousness level assessment in the poisoned patient using the alert/verbal/painful/unresponsive scale and the Glasgow Coma Scale. Ann Emerg. Med. 44, 108-113.

Khine, H.H., Corddry, D.H., Kettrick, R.G., Martin, T.M., McCloskey, J.J., Rose, J.B., Theroux, M.C., Zagnoev, M., 1997. Comparison of cuffed and uncuffed endotracheal tubes in young children during general anesthesia. Anesthesiology. 86, 627-631.

Kincaid, E.H., Chang, M.C., Leton, R.W., Chen, J.G., Meredith, J.W., 2001.Admission base deficit in pediatric trauma: A study using the national trauma data bank. J. Trauma. 51, 332-335.

King, B.R., Baker, M.D., Braitman, L.E., Seidl-Friedman, J., Schreiner, M.S., 1993. Endotracheal tube selection in children: A comparison of four methods. Ann Emerg. Med. 22, 530-534.

Leonard, M., Sproule, J., McCormack, D., 2007. Pediatricspinal trauma and associated injuries. Injury. 38, 188-193.

Levin, H.S., Culhane, K.A., Mendelsohn, D., Lilly, M.A., Bruce, D., Fletcher, J.M., Chapman, S.B., Harward, H., Eisenberg, H.M., 1993. Cognition in relation to magnetic resonance imaging in head-injured children and adolescents. Arch Neurol. 50, 897-905.

Linzer, J.F., 2010. Do Routine Laboratory Tests Add to the Care of the Pediatric Trauma Patients? Clin. Pediatr. Emerg. Med. 11, 18-21.

Moss, R.L., Musemeche, C.A., 1996. Clinical judgement is superior to diagnostic tests in the management of pediatric small bowel injury. J. Pediatr. Surg. 31, 1178-1182.

Namias, N., McKenney, M.G., Martin, L.C., 1996. Utility of admission chemistry and coagulation profiles in trauma patients: a reappraisal of traditional practice. J. Trauma. 41, 21-25.

Newman, K.D., Bowman, L.M., Eichelberger, M.R., Gotschall, C.S., Taylor, G.A., Johnson, D.L., Thomas, M., 1990. The lap belt complex: intestinal and lumbar spine injuries and seatbelt use. J. Trauma. 30, 1133-1138.

Osler, T.M., Vane, D.W., Tepas, J.J., Rogers, F.B., Shackford, S.R., Badger, G.J., 2001. Do pediatric trauma centers have better survival rates than adult trauma centers? An examination of the national pediatric trauma registry. J. Trauma. 50, 96-101.

Patel, J.C., Tepas, J.J., Mollitt, D.L., Pieper, P., 2001. Pediatric cervical spine injuries: Defining the disease. J. Pediatr. Surg. 36, 373-376.

Patrick, D.A., Bensard, D.D., Moore, E.E., Karrer, F.M., 1999. Nonoperative management of solid organ injuries in children results in decreased blood utilization. J. Pediatr. Surg. 34, 1695-1699.

Phipps, L.M., Thomas, N.J., Gilmore, R.K., Raymond, J.A., Bittner, T.R., Orr, R.A., Robertson, C.L., 2005. Prospective assessment of guidelines for determining appropriate depth of endotracheal tube placement in children. Pediatr. Crit. Care Med. 6, 519-522.

Potoka, D.A., Saladino, R.A., 2005. Blunt Abdominal Trauma in the Pediatric Patient. Clin. Pediatr. Emerg. Med. 6, 23-31.

Ruddy, R.M., 2005. Trauma and pediatric lung. Paediatric Respiratory Reviews. 6, 61-67.

Ruppert, M., Van Hee, R., 2001. Creatinine-kinase-MB determination in noncardiac trauma: its difference with cardiac infarction and its restricted use in trauma situations. Eur. J. Emerg. Med. 8, 177-179.

Scaife, E.R., Fenton, S.J., Hansen, K.W., Metzger, R.R., 2009. Use of focused abdominal sonography for trauma at pediatric and adult trauma centers: a survey. J. Pediatr. Surg. 44, 1746-1749. 
Simon, H.K., Muehlberg, A., Linakis, J.G., 1994. Serum amylase determinations in pediatric patients presenting to the ED with acute abdominal pain or trauma. Am J. Emerg. Med. 12, 292-295.

Sözübir, S., Tander, B., Bernay, F., Arıtürk, E., Rızalar, R., Gürses, N., 2005. Traumatic diaphragmatic rupture in children. Ulus Travma Acil Cerrahi Derg. 11, 64-68.

Stylianos, S., Ford, H.R., 2008. Outcomes in pediatric trauma care. Seminars in Pediatr. Surg. 17, 110-115.

Testerman, G.M., 2006. Surgeon-performed ultrasound in the diagnosis and management of pericardial tamponade in a 20-month-old blunt injured toddler. Tenn Med. 99, 37-38.

Wilson, R.H., Moorehead, R.J., 1992. Management of splenic trauma. Injury. 23, 5-9.

Woodcock, R.J., Davis, P.C., Hopkins, K.L., 2001. Imaging of head trauma in infancy and childhood. Semin Ultrasound, CT, and MRI,. 22, 162-182.

Woosley, C.R., Mayes, T.C., 2008. The pediatric patient and thoracic trauma. Semin Thorac Cardiovasc Surg. 20, 5863.

Vella, A.E., Wang, V.J., McElderry, C., 2006. Predictors of fluid resuscitation in pediatric trauma patients. J. Emerg. Med. 31, 151-155. 